\title{
End-Ordovician ostracod faunal dynamics in the Baltic Palaeobasin
}

\author{
Karin Truuvera,b, Tõnu Meidla ${ }^{\mathrm{a}}$ and Oive Tinn ${ }^{\mathrm{a}}$ \\ ${ }^{\text {a }}$ Department of Geology, University of Tartu, Ravila 14A, 50114 Tartu, Estonia; karin.truuver@ut.ee \\ b Estonian Museum of Natural History, Lai 29a, 10133 Tallinn, Estonia; Karin.Truuver@loodusmuuseum.ee \\ Received 15 May 2020, accepted 30 July 2020, available online 11 February 2021
}

\begin{abstract}
The Late Ordovician Baltic Palaeobasin (BPB) offered a favourable environment for a diverse and abundant ostracod fauna to thrive across the basin. A short period of unstable environmental conditions at the end of the Ordovician, the Hirnantian glaciation, and the concurrent extinction event completely rearranged the ostracod associations. Statistical analyses reveal temporal (diverse pre-glacial, more uniform glacial and poorly diverse post-glaciation faunas) and geographical (upper shelf and middle shelf faunas) separation of ostracod associations in the BPB. The geographical division applies to the pre-glacial and glacial faunas only; the scanty post-glacial fauna found in deeper-water sections is uniform. Ostracod associations are distinct both in a temporal and geographical sense. Juxtaposing ostracod data with $\delta^{13} \mathrm{C}$ curves shows that the typical Hirnantian Harpabollia harparum fauna in the BPB appeared near the peak of a $\delta^{13} \mathrm{C}$ excursion. This might explain why the H. harparum fauna seems to appear first in deeperwater sections and is absent or appears later in shallower-water sections. The majority of the nearshore sections in Estonian and Lithuanian shelves lack most or all of the Hirnantian strata. The lowermost Hirnantian is preserved in only a few sections (e.g. Männamaa and Puhmu in Estonia).

The appearance of the post-glacial ostracod fauna, which most probably was a survival fauna rather than a recovery fauna, is related to the falling limb of the $\delta^{13} \mathrm{C}$ curve. The appearance of this fauna was previously considered as a marker of the Ordovician-Silurian boundary in the region but, according to the present understanding, took place in the late Hirnantian.
\end{abstract}

Key words: Late Ordovician, Baltic Palaeobasin, ostracod, glaciation, HICE, extinction.

\section{INTRODUCTION}

Due to a severe climate event, the Hirnantian glaciation, the end-Ordovician world was climatically one of the harshest and most unstable times to live on our planet. This event has received an increasing amount of attention over the last couple of decades regarding its possible causes (e.g. Marshall \& Middleton 1990; Brenchley et al. 1994; Kump et al. 1999; Buggisch et al. 2010; Sell et al. 2013; Morris et al. 2018), duration (e.g. Brenchley et al. 1994; Kaljo et al. 2003; Trotter et al. 2008; Turner et al. 2011) and effects on biota (e.g. Kaljo et al. 2008; Finnegan et al. 2011; Rasmussen \& Harper 2011; Hammarlund et al. 2012; Harper et al. 2014; Long et al. 2015; Vandenbroucke et al. 2015). This glaciation affected all faunal groups, but the severity of changes and the extinction patterns differ from group to group, mostly owing to their biological traits and ecological preferences (Finnegan et al. 2012). The progression and regression of the glaciation are recorded also in the $\delta^{18} \mathrm{O}$ and $\delta^{13} \mathrm{C}$ curves that display significant positive shifts in the early and mid-Hirnantian. These fluctuations have been widely used as a secondary boundary marker of the Hirnantian Stage, in parallel with the biostratigraphic criteria.

The global correlation of the Hirnantian is generally well resolved, being based on coeval changes in graptolite faunas and stable carbon isotopic curves. At the same time correlation problems persist in the areas where graptolites are not common, as in Baltoscandia. Correlations in these areas are based on the occurrences of the well-known Hirnantia fauna (brachiopods, trilobites and other shelly fossil groups), conodonts and chitinozoans (Wang et al. 2019 and references therein).

Due to their high sensitivity to environmental changes (Boomer et al. 2003; Tinn et al. 2006), ostracods were one of the animal groups most affected by this event. While available ostracod data are not uniform throughout the world, the data from the well-studied Baltic Palaeobasin (BPB) suggest that during the latest Ordovician, ostracod associations were entirely rearranged in this region (Meidla 1996a, 1996b, 2007; Tinn et al. 2006; Truuver et al. 2012; Truuver \& Meidla 2015). The key elements

(C) 2021 Authors. This is an Open Access article distributed under the terms and conditions of the Creative Commons Attribution 4.0 International Licence (http://creativecommons.org/licenses/by/4.0). 
of the newly appearing fauna, the so-called Harpabollia harparum association, have a considerably wider geographic distribution than the Katian assemblages. This association is thought to be a part of the Hirnantia fauna in wider sense, i.e. the well-known assemblage of various shelly fossils characteristic of the Hirnantian Stage (Meidla 2007).

The present paper addresses the dynamics of the ostracod assemblages in the Ordovician-Silurian transition interval of the Baltic Region, based on published and new data from Estonia, Latvia, Lithuania, Poland and Sweden. Particular attention is paid to the relationships and timing of the Harpabollia harparum association in the area and to new insights in the regional stratigraphy in the Ordovician-Silurian transition interval.

\section{MAJOR EVENTS DURING THE LATE ORDOVICIAN}

The Ordovician Period ended with a glaciation on the Gondwana supercontinent. The timing and causes of the climate changes are both subjects of a heated discussion. The 'classical' view of this event is based on a long Ordovician greenhouse period interrupted by the shortlived Hirnantian glaciation that caused one of the major extinctions in Earth history (e.g. Brenchley et al. 1994). Brenchley et al. (1994), Hallam \& Wignall (1997) and Finnegan et al. (2011) suggested that the glaciation was abrupt and short, lasting about 0.5-1 Ma. A number of more recent papers (e.g. Kaljo et al. 2003; Saltzman \& Young 2005; Buggisch et al. 2010; Rosenau et al. 2012; Sell et al. 2013) suggest that the cooling may have started earlier, around the Sandbian-Katian boundary. Some authors place the beginning of cooling or glaciation already in the late Early Ordovician (Trotter et al. 2008; Vandenbroucke et al. 2010; Turner et al. 2011), although no firm and well-dated sedimentological evidence of preHirnantian glaciation(s) (tillites, dropstones) is known.

There has been much debate about what exactly triggered the (end-)Ordovician cooling, but the true mechanism is yet to be determined. The two 'classical' hypotheses are the organic burial hypothesis (increasing latitudinal temperature differences changed the ocean circulation pattern enhancing organic productivity and carbon burial, which reduced dissolved $\mathrm{pCO}_{2}$ in sea water and atmosphere - Marshall \& Middleton 1990; Brenchley et al. 1994) and the silicate weathering hypothesis (intensified silicate terrain exposure and weathering due to the Taconic orogeny lowering marine and atmospheric $\mathrm{CO}_{2}$ levels - Kump et al. 1999). More recently, Lenton et al. (2012) and Morris et al. (2018) suggested that the appearance and spread of the first land plants increased the weathering of silicate rocks, causing the drawdown of atmospheric $\mathrm{CO}_{2}$ and flow of phosphorus into the oceans enhancing the production of organic matter and organic carbon burial. According to Buggisch et al. (2010), cooling started after the biggest single volcanic eruption in the Phanerozoic - the Deicke eruption in the late Sandbian. Several researchers disagree with that opinion, relying on $\delta^{18} \mathrm{O}$ data (Herrmann et al. 2010; Rosenau et al. 2012) and the interpretation of more detailed datasets obtained with new geochemical methods (Sell et al. 2013).

It is also generally accepted that the end-Ordovician glaciation coincided with a prominent extinction event although the questions of how and to what extent these events are related to one another are still debated. Sheehan (1973), Berry \& Boucot (1973) and Brenchley \& Newall (1984), followed later by Finnegan et al. (2011), link the mass extinction directly to the glaciation-induced cooling. Wilde \& Berry (1984) and Marshall \& Middleton (1990) place the blame on nutrient-rich polar water flux to continental shelves, causing bloom and rapid eradication of organic matter. Rasmussen \& Harper (2011) admit the role of climate change but emphasize the closing of the Iapetus Ocean and related habitat loss, reinforced later by the sea level drop, as the main contributor to the extinction. Hammarlund et al. (2012) suggest that euxinic conditions of the Hirnantian intensified organic carbon burial in deep sea sediments, releasing more and more phosphorus, which in turn increased productivity and led to severe anoxia by the first half of the Hirnantian. Harper et al. (2014) conclude that the aforementioned factors probably acted together, resulting in the remarkable extinction event. After documenting an exceptional rise in the amount of dissolved metals $(\mathrm{Fe}, \mathrm{Mo}, \mathrm{Pb}, \mathrm{Mn}$ and As) in the ocean water and linked malformations of fossil plankton, Vandenbroucke et al. (2015) suggested that the oceanic anoxia was responsible for seawater toxicity. Long et al. (2015) pointed at a prolonged ( 10 Ma) period of selenium depletion prior to the end-Ordovician glaciation, and end-Devonian and end-Triassic extinction events.

\section{REMARKS ON THE STRATIGRAPHY OF THE ORDOVICIAN-SILURIAN BOUNDARY STRATA}

The Upper Ordovician and basal Silurian limestone succession in Estonia and adjacent areas contains a major gap caused by the sea-level drop related to the Hirnantian glaciation (see Fig. 1). The sea-level drop makes this part of the succession, the Porkuni Regional Stage, discontinuous in all sections. The position of the Porkuni Regional Stage in the topmost part of the Ordovician was generally accepted for decades in Estonia and adjacent areas but some correlation problems still persist. The scarcity of graptolites in the 
K. Truuver et al.: End-Ordovician ostracod faunal dynamics

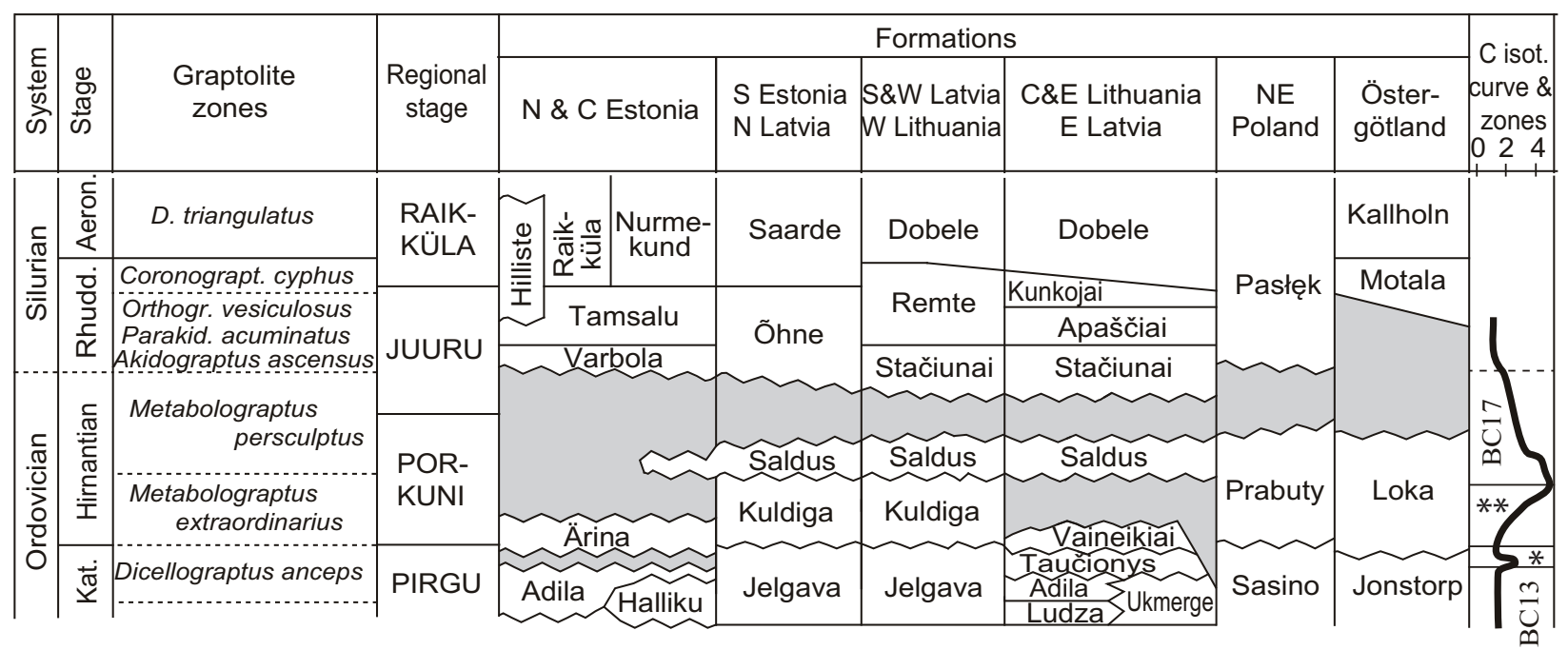

Fig. 1. Stratigraphy of the Ordovician-Silurian boundary strata, compiled mainly after Modliński \& Podhalańska (2010), Bergström et al. (2011), Lukševičs et al. (2012), Männik (2014), Meidla et al. (2014) and Truuver \& Meidla (2015). The stratigraphic position of the Vaineikiai Formation is after Laškovas (2004) and the position of the Dobele Member according to Lapinskas (2004). The position of the lower boundary of the Silurian System in the Juuru Regional Stage in Estonia, Latvia and Lithuania is unclear at the moment but it will likely be drawn within the Varbola or Tamsalu, Õhne and Stačiunai formations. Bergström \& Bergström (1996) demonstrate the diachroneity of the lower boundary of the Motala Formation and Truuver et al. (2012) suggest a pre-Hirnantian age for the lower part of the Loka Formation in Östergötland. The Baltic stable carbon isotopic zones are adopted from Ainsaar et al. (2010); * marks the isotopic zones BC14-BC15 and ** the isotopic zone BC16. Abbreviations: Kat., Katian; Rhudd., Rhuddanian; Aeron., Aeronian; N, north; E, east; S, south; W, west; C, central; D. triangulatus, Demirastrites triangulatus; Coronograpt. cyphus, Coronograptus cyphus; Orthogr. vesiculosus, Orthograptus vesiculosus; Parakid. acuminatus, Parakidograptus acuminatus.

Ordovician-Silurian transition interval and sharp biofacies differences of shelly faunas hamper the correlation of principal rock units. In papers of the previous decades, the Ärina Formation in North Estonia is correlated with some part of the succession of the Kuldiga and Saldus formations in the Livonian Basin, whilst relative positions of the graptolite, chitinozoan and conodont biozones in this interval vary markedly (compare, for example, Männil \& Meidla 1994; Nõlvak et al. 2006; Kaljo et al. 2008; Meidla et al. 2014). Although the majority of papers published in the Baltoscandian regions have until recently accepted the Porkuni Regional Stage as equivalent to the global Hirnantian Stage, it does not include the late Hirnantian that is equivalent to the lower part of the Juuru Regional Stage, formerly considered the basal Silurian (Bauert et al. 2014; Hints et al. 2014; Meidla et al. 2014; Ainsaar et al. 2015). These correlations will be addressed in the discussion part of this manuscript.

\section{LATE ORDOVICIAN OSTRACOD PALAEOBIOGEOGRAPHY}

The taxonomy of ostracods in this paper generally follows Vannier et al. (1989) and Meidla (1996b). Three principal suborders in the interval of the Ordovician-Silurian transition are Palaeocopa, Binodicopa and Metacopa, with minor numbers of Leiocopa, Punciocopa, Cypridocopa, Cytherelliformes, Paraparchitocopa and Eridostraca (see Vannier et al. 1989 for morphological details).

Faunal links between Baltoscandia and Laurentia (North America) across the Iapetus Ocean, Avalonia (British Isles) and the northern margin and periphery of Gondwana (Carnic Alps and Bohemia in particular) in the Late Ordovician are addressed in a number of papers (Schallreuter \& Siveter 1985; Vannier et al. 1989; Meidla 1996b, 2007; Mohibullah et al. 2012; Meidla et al. 2013). The results indicate ostracod migration between the palaeocontinents. About 30 ostracod genera are common to these continents. Binodicopes, one of the major ostracod groups (suborders) in the Ordovician, show the largest number of common species. In terms of suborders, the taxonomic structure of the Ordovician ostracod fauna in the British Isles is similar to that of Baltoscandia, only the dominance of palaeocopes over binodicopes is less evident. On the family level, the binodicope faunas of Baltoscandia and the British Isles are very similar. The generic similarity of palaeocopes and binodicopes, both in the generic and species level between Avalonia and Baltoscandia, increases towards the Late Ordovician. Nearly all palaeocope genera recognized in the Ashgill of 
Great Britain are recorded also in the coeval sediments in Baltoscandia (Vannier et al. 1989; Siveter 2009).

Binodicopes dominate the ostracod associations in Ibero-Armorica that was attached to high-latitude Gondwana (Torsvik \& Cocks 2013). Yukon (Laurentia) had some faunal links with shallow-water Baltica, especially in the latest pre-Hirnantian (Meidla et al. 2013).

\section{MATERIAL}

The ostracods addressed in this study were mostly collected from drill cores, in some cases also from outcrops like, e.g. the North Estonian sections of Porkuni, Siuge and SeliRussalu, quondam Borenshult (not accessible nowadays) and Råssnäsudden sections in southern Sweden (see Fig. 2). The distribution data come mainly from published sources (Meidla 1996b; Sidaravičiene 1996; Brenchley et al. 2003; Truuver et al. 2012; Männik 2014; Truuver \& Meidla 2015) but is in some parts (drill cores) complemented with previous unpublished quantitative information.

The rock material is carbonate, mostly limestone and marl. The pre-Hirnantian limestones are in some cases nodular (e.g. in South Estonia), clayey (sections in the deeper part of the basin, e.g. North and Northeast Poland), partly dolomitized or contain a large quantity of skeletal debris (especially in North Estonian sections). The Hirnantian limestones are frequently oolitic (especially within the Livonian basin) or contain coarse siliciclastic material, both indicative of nearshore sedimentary environments.

Sections vary both in the temporal range and stratigraphic contiguity. The sections in North and Central Estonia are lacking or almost lacking Hirnantian strata. The latest Ordovician reef limestones within the Ärina Formation (e.g. the Porkuni, Seli-Metsküla, Seli-Russalu and Siuge outcrops and the Puhmu drill core) are usually dated as early Hirnantian (e.g. Kaljo et al. 2001; Hints \& Männik 2014) but significant faunal differences compared to well-dated units within the Livonian Basin should be emphasized (Meidla 1996a, 1996b, 2007).

The Livonian Basin (sensu Harris et al. 2004) represented the deeper part of the Baltic Palaeobasin. Most of the sections within this area contain one or several gaps within or at the boundaries of the Kuldiga and Saldus formations (e.g. Taagepera, Riekstini and Paroveja drill cores). Some sections are missing the upper Saldus Formation (e.g. Otepää drill core). Ostracod associations in these formations are usually not poor but generally less diverse than the pre-Hirnantian associations. A very low

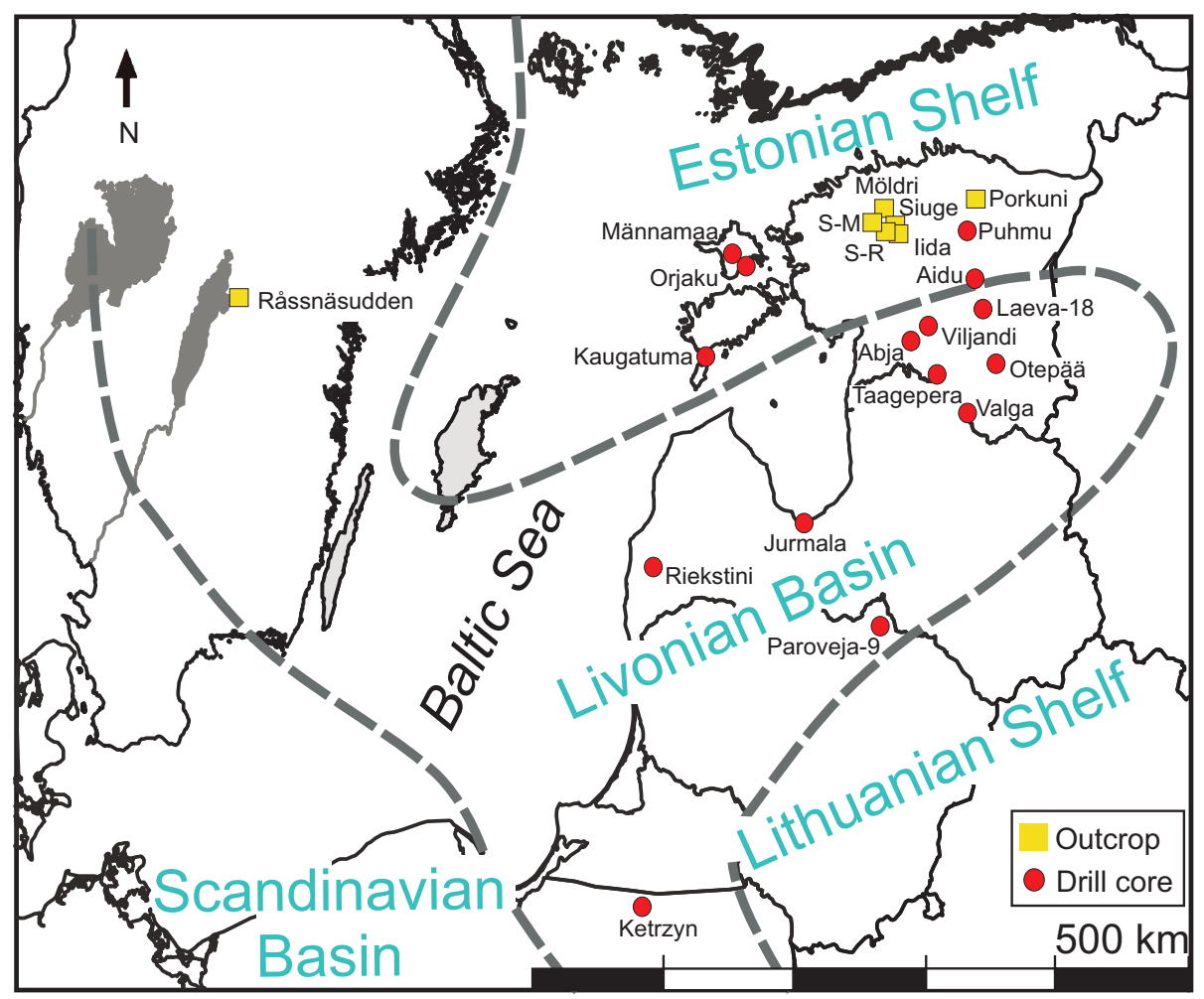

Fig. 2. Map of the study area and the sections used in this study. Modified from Meidla (1996b) and Harris et al. (2004). S-M - SeliMetsküla, S-R - Seli-Russalu. 
fossil content in the Saldus Formation is most likely partly due to its specific composition: oolitic limestones are barren as ostracods have been 'washed out' and microlaminated (and occasionally sandy) limestones were formed in extremely shallow-water conditions. The most complete section in this area is the Jurmala section in Latvia (Fig. 2), which displays a nearly continuous carbonate succession from the Katian up to the Rhuddanian Stage (Meidla et al. 2011).

\section{DATA ANALYSIS}

\section{Parent dataset}

The parent dataset was constructed as a data matrix with locality, sample, stratigraphic and species data. The information originated from: (1) newly collected data from core sections and outcrops and (2) relevant literature, which was examined in the course of the compilation of this database (Fig. 2). However, due to different levels of generalization (lack of detail), this information was not always usable for detailed statistical analyses (see supplementary data at https://doi.org/10.23679/505).

From this parent dataset we restricted the study to species and samples with more than one sample/taxonomic occurrence. In the analysed data matrix (see supplementary online material: ostracod data matrix at https://doi.org/10.23679/505), the Katian is represented by 103 samples, the Hirnantian by 34 samples and the late Hirnantian-Silurian transition (late HirnantianRhuddanian, designated as 'Juuru' below) by 11 samples. Several samples of the initial dataset were excluded because of too low diversity. Altogether we analysed 148 samples from 20 localities. As a whole, the matrix contains data about 15983 ostracod specimens from 116 species, 71 genera and 8 suborders.

Analyses were carried out using the PAST statistical package version 4.01 (Palaeontological Statistics; Hammer et al. 2001).

\section{Cluster analysis}

The non-metric multidimensional scaling (NMDS) ordination and UPGMA (unweighted pair group method of linkage) cluster analyses were conducted on the presence/absence matrix using the Jaccard similarity index as a distance measure. The UPGMA clustering (also known as average linkage or mean linkage clustering), where the distance between two clusters is defined as the average of all possible distances (Hammer \& Harper 2005), helps to distinguish and illustrate different groups in the dataset and is often used in the ecological analyses.
The UPGMA analyses resulted in five major clusters (Fig. 3). The hypothesis that five groups are present was tested using Analysis of Similarity (ANOSIM). The computed $R$ value is 0.78 , showing a high level of dissimilarity between the clusters, and $p$ indicates that this separation is statistically significant $(p=0.0001)$.

The five clusters, named Katian 1, Katian 2, Hirnantian 1, Hirnantian 2 and Juuru, represent concurrently stratigraphical and biogeographical units (table in supplementary online material at https://doi.org/10.23679/505). While both Katian 1 and Katian 2 incorporate taxa of Katian age, the main distinction between these two clusters lies in the geographical, rather than temporal, distribution of the studied samples. Katian 2 comprises mainly localities/samples from the southern and western parts of the study area representing the deeper part of the ancient BPB (Kętrzyn, Råssnäsudden, Paroveja and South Estonia), while Katian 1 encompasses localities/ samples from North Estonia - the shallow part of the BPB. However, the distinction between these regions/localities is not strict. Hence, both clusters include samples from the Abja, Taagepera, Puhmu and Paroveja sections. Similarly, the clusters Hirnantian 1 and Hirnantian 2 comprise taxa of Hirnantian age, but from different parts of the study area. The samples of Hirnantian 2 come from the southern part of the study area (Abja, Otepää, Taagepera, Kętrzyn), those of Hirnantian 1 from Central and North Estonia. Taagepera is the only section where the Hirnantian samples appear in both clusters. The fifth cluster, Juuru, comprises samples from the Laeva, Aidu, Viljandi and Råssnäsudden sections.

The taxonomic composition of the clusters is presented in Fig. 4. The analysis of all clusters included (1) the average proportion of genera, based on counts of individuals/ specimens per genus, (2) the average proportion of suborders, based on counts of individuals/specimens per suborder and (3) the average proportion of suborders, based on counts of genera per suborder.

The second largest cluster, Katian 2, demonstrates the highest richness level, comprising 80 species from eight suborders. It mainly includes specimens of two species the metacopes Rectella romboformis and Steusloffina cuneata. The largest cluster is Katian 1, which comprises 49 species from five suborders, mostly representatives of two metacope species - Daleiella rotundata and Rectella romboformis. Hirnantian 1 comprises 52 species from six suborders, whereas the metacope Steusloffina cuneata forms about $25 \%$ of all specimens. Hirnantian 2 comprises 25 species from six suborders with Circulinella gailitae and Cryptophyllus pius being the most abundant. The Rhuddanian cluster shows the lowest richness level with seven species from two suborders only. Nearly half of the specimens in the Rhuddanian cluster represent the metacope species Longiscula smithii. 

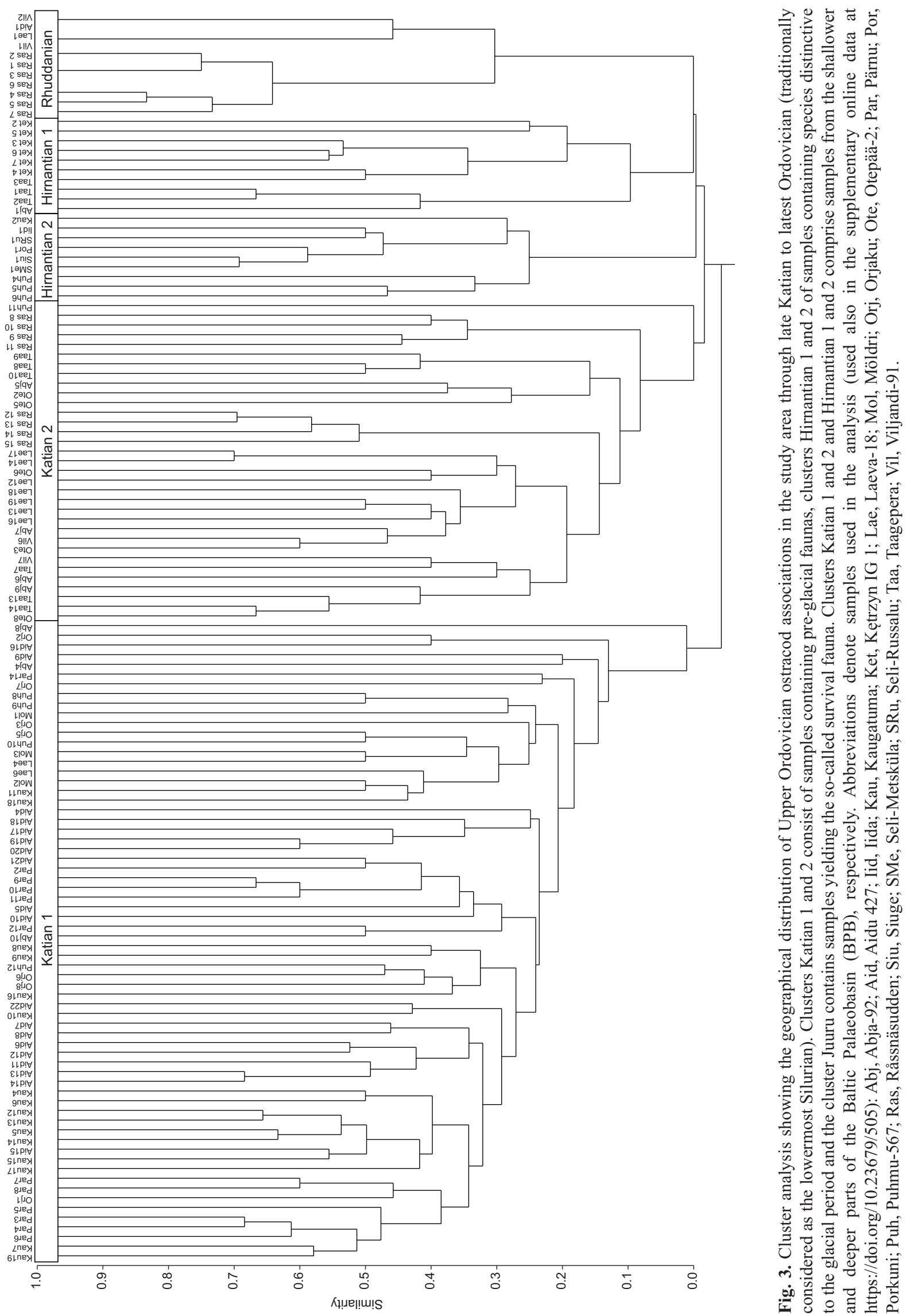
Rhuddanian. suborders : individuals

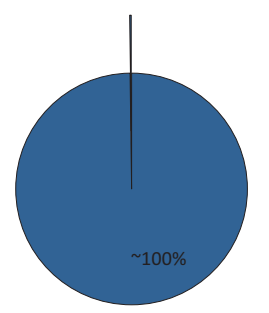

Hirnantian 2. suborders : individuals

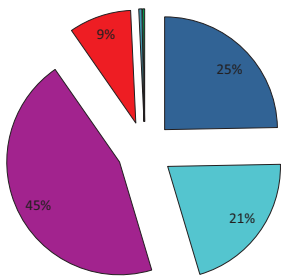

Hirnantian 1. suborders : individuals

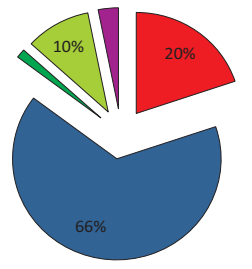

Katian 2. suborders : individuals

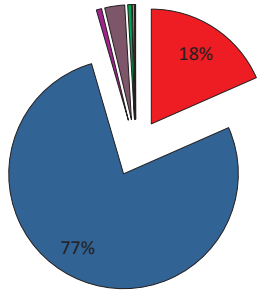

Katian 1. suborders : individuals

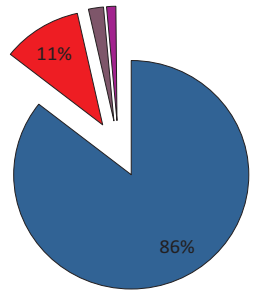

Palaeocopa

$\square$ Metacopa

$\square$ Binodicopa

Leiocopa
Rhuddanian. suborders : genera

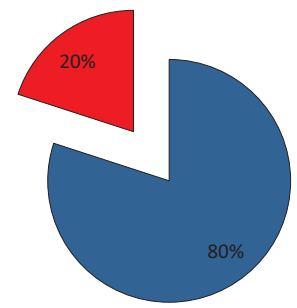

Hirnantian 2. suborders : genera

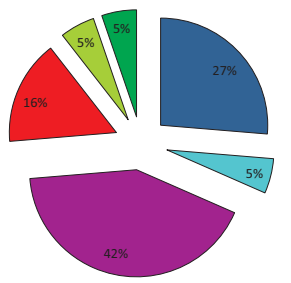

Hirnantian 1. suborders : genera

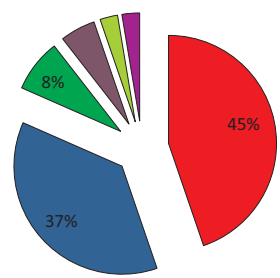

Katian 2. suborders : genera

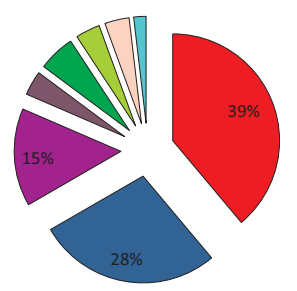

Katian 1. suborders : genera

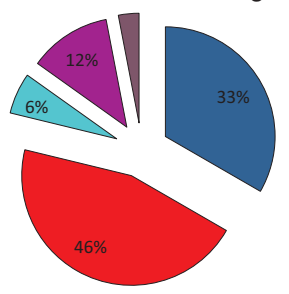

Cypridocopa

Cytherelliformes

Paraparchitocopa

Eridostraca

Fig. 4. Pie diagrams for the five clusters (Katian 1 and 2, Hirnantian 1 and 2, and Juuru) showing the relative proportion of individuals per genera and suborders in these groups. The two series of diagrams demonstrate the differences between faunal diversity, depending on the taxonomic level of investigation. 
The biodiversity indices (Shannon index, dominance and evenness) for all five associations/clusters, and for comparison for the total dataset, illustrating the structure
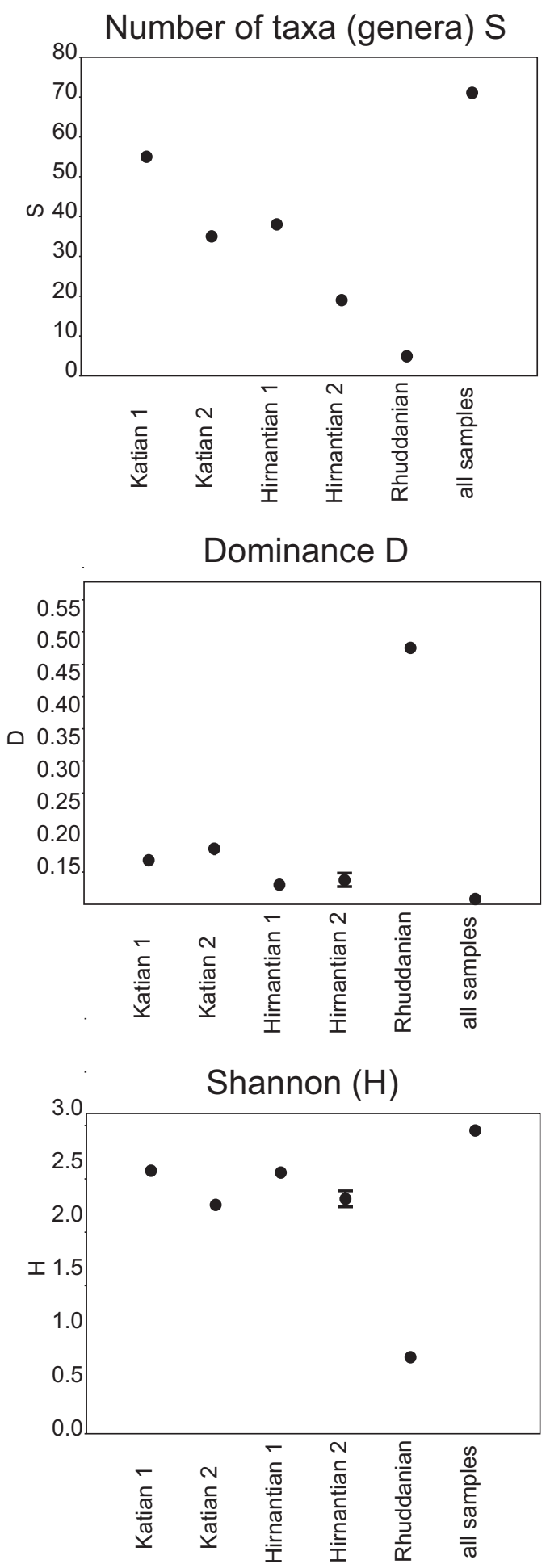

of these assemblages, are plotted in Fig. 5. The dominance and Shannon indices are relatively similar $(0.1-0.2$ and 2.0-2.5, respectively) for all Katian and Hirnantian
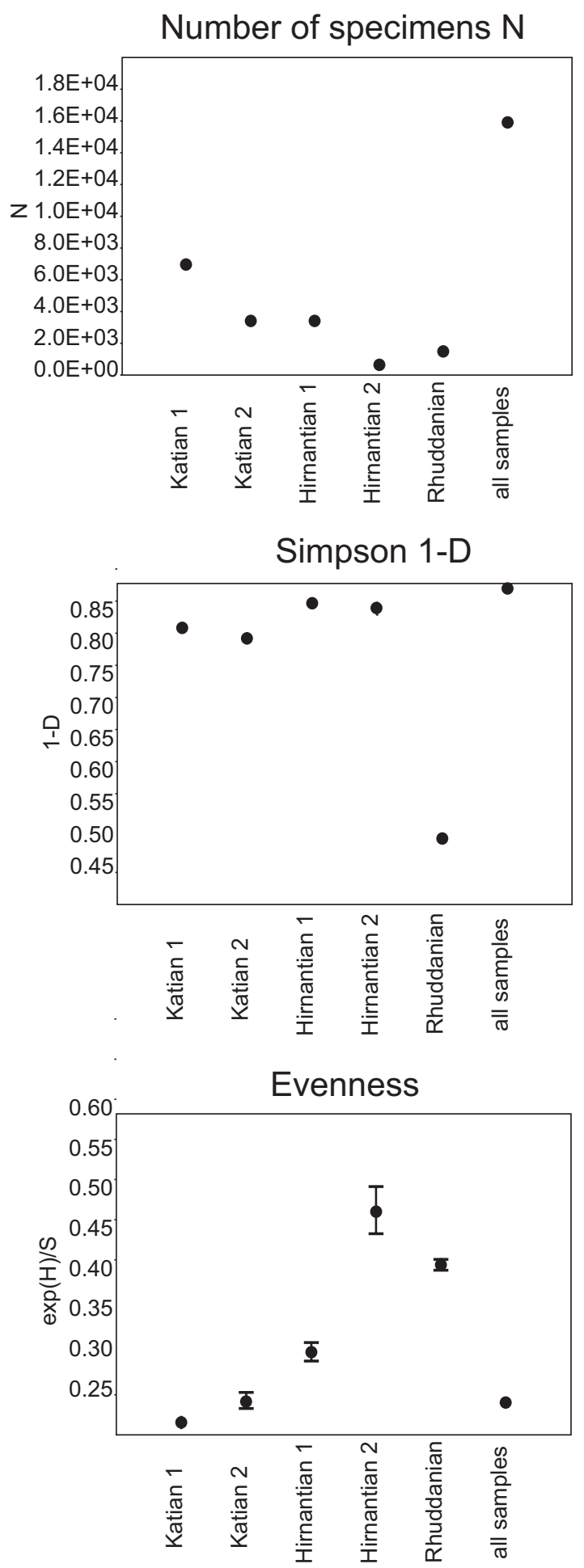

Fig. 5. Plots comparing different diversity indices (Shannon index, dominance and evenness) for the Katian, Hirnantian and Juuru (Rhuddanian) clusters and the total dataset. 
associations/clusters, but differ significantly for the Rhuddanian cluster, which shows a higher dominance value (0.5) and a lower Shannon index (0.7). Evenness values are low $(<0.3)$ in both Katian and Hirnantian 1 samples, but considerably higher in Hirnantian 2 and Rhuddanian samples (0.4-0.5).

\section{Detrended correspondence analysis}

Detrended correspondence analysis (DCA) was performed on the same dataset, in order to provide an alternative visualization for the Katian, Hirnantian and Rhuddanian ostracod assemblages of the Baltic area. As one of the tools for multidimensional data analysis in ecology and palaeontology, DCA is discussed in detail by Clapham (2011) and Correa-Metrio et al. (2014) (see also references therein). It has been argued that the detrending process may yield more accurate and interpretable ordination results especially for long ecological gradients or in the case of rapid ecological turnover (Clapham 2011).

The five polygons (convex hulls) in Fig. 6 represent the five clusters shown in Fig. 3. For simplicity, only the data points for the samples are shown. Two primary gradients can be observed. Axis 1 (with an eigenvalue of $0.9796)$ explains a large part of the total variation. The eigenvalue of axis 2 is 0.5921 , and those of axes 3 and 4 are 0.2853 and 0.2095 , respectively. Possible interpretations of the axes are discussed below.

\section{Venn diagrams}

Venn diagrams (Fig. 7) show the distribution of shared taxa (genera) among the five ostracod clusters illustrated in Fig. 3. The diagrams were produced with the tool InteractiVenn (Heberle et al. 2015).

\section{BIODIVERSITY, FAUNAL COMPOSITION AND GENERAL ASSEMBLAGE STRUCTURE OF OSTRACODS IN THE ORDOVICIAN-SILURIAN BOUNDARY INTERVAL OF BALTOSCANDIA}

Ostracod diversity in the BPB started to rise after a major faunal rearrangement in the early Katian. The diversity peak was reached in the late Katian (in the Pirgu Regional Stage) and was followed by a decline towards the end of the Katian and Hirnantian in all facies zones (Meidla 1996b). The decline also brought along changes in the taxonomic composition of assemblages: the generic diversity of palaeocopes and cytherelliformes dropped, the diversity of podocopes, leiocopes and binodicopes rose and eridostracans occupied a more prominent position in most parts of the palaeobasin (Fig. 4; Meidla 1996b; Sidaravičiene 1996; Brenchley et al. 2003; Truuver et al. 2012; Truuver \& Meidla 2015).

Vannier et al. (1989) emphasize the high spatial heterogeneity and niche-partitioning of ostracods in Baltoscandia and use these features as an environmental indicator: a low palaeocope/binodicope ratio is characteristic of a high-stress terrigenous sedimentary environment and a high ratio of a carbonate environment (Vannier et al. 1989; Meidla 1996a). The palaeocope/binodicope ratio in Baltoscandia was 3/1 on generic level and 5/1 on species level through most of the Ordovician, except for the end of the period (Vannier et al. 1989; Meidla 1996a).

Palaeocopes (54\% of genera) were the richest and most diverse suborder in the Upper Ordovician of Baltoscandia. Binodicopes constituted also one of the main groups (18\% of genera). Metacopes formed about $9 \%$ of all genera and other suborders (see Fig. 4) together comprised $19 \%$ of the material. At the same time, the distribution of the species and genera, as well as of higher taxa, is markedly uneven between the clusters shown in Fig. 3 (see Fig. 4).

According to the currently accepted correlation, there are two principal Hirnantian ostracod assemblages in Baltica: (1) the high-diversity metacope-dominated assemblage and (2) the low-diversity binodicope-dominated H. harparum assemblage (Meidla 1996a, 1996b, 2007; Meidla et al. 2013). The first assemblage is dominated by metacope ostracods (e.g. Medianella aequa, Steusloffina aequa, Medianella intecta). It is endemic and restricted to northern Estonia where it is described in limestones of the Ärina Formation. This assemblage is often associated with a Hirnantia-Dalmanitina brachiopod and trilobite fauna that is considered diagnostic of the Hirnantian in Baltoscandia (Brenchley et al. 2003; Meidla 2007) and ranges into the Metabolograptus persculptus graptolite Biozone (Meidla 2007; Bergström et al. 2011; Truuver \& Meidla 2015). Its distribution is restricted to South Sweden, West Latvia, West Lithuania, North and Northeast Poland, together comprising the Livonian and Scandinavian basins (Fig. 2). The second, binodicopedominated assemblage is mostly confined to deeper-water siliciclastic shelf settings but also reached shallow-water, high-energy stressed environments (the Saldus Formation - like in the Ruhnu and Jurmala cores; Brenchley et al. 2003; Meidla et al. 2011). There are also some intercontinental species links: Scanipisthia rectangularis appears also in Bohemia (part of Gondwana; Torsvik \& Cocks 2017) and in the Carnic Alps (Northern margin of Gondwana; ibid.) and Harpabollia harparum is recorded in South America (Reily et al. 2018).

The composition of the $H$. harparum assemblage is specific and unique - it displays only weak links to the pre-Hirnantian ostracod assemblages of the study area. 


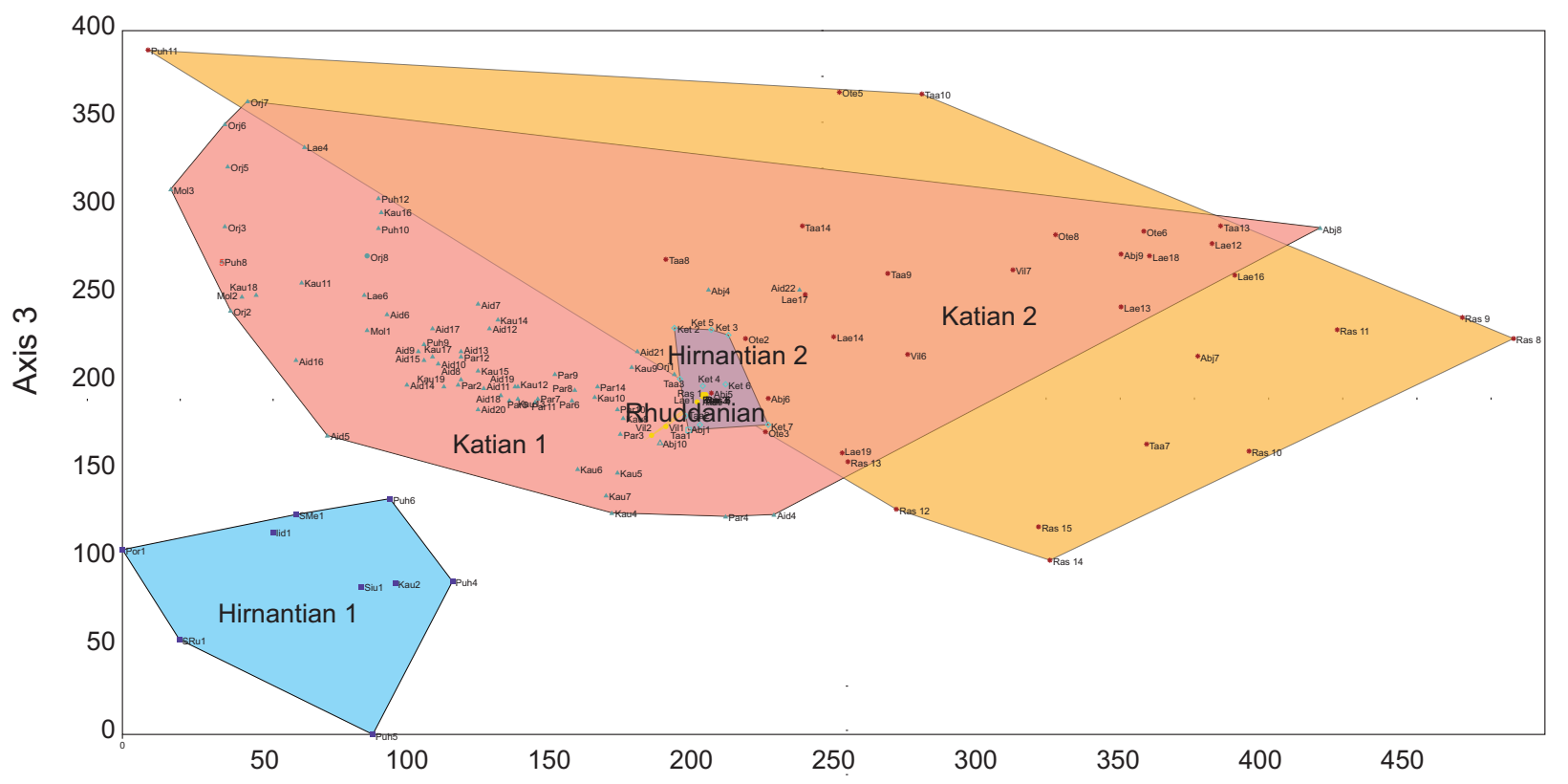

Axis 2

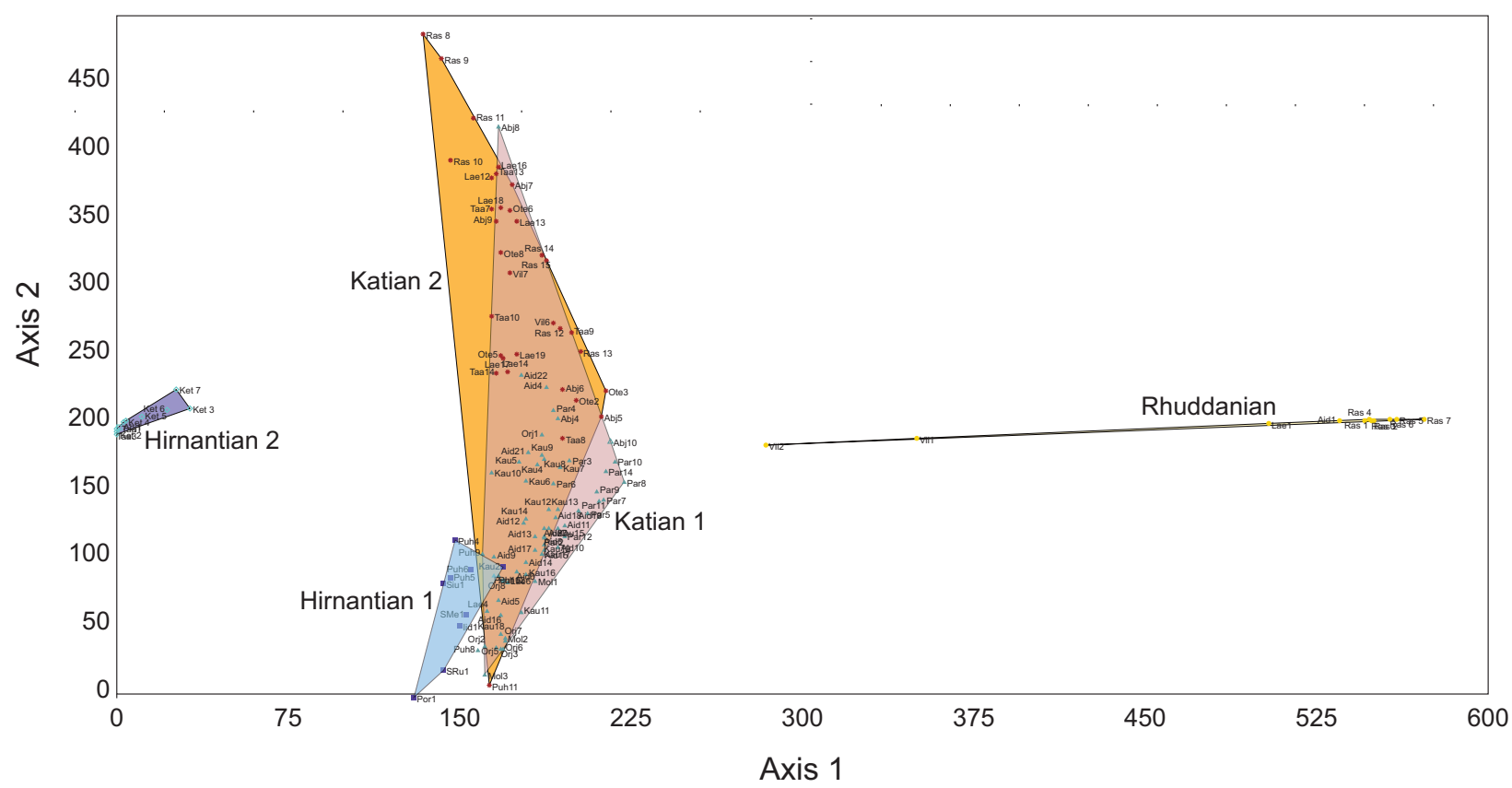

Fig. 6. Detrended corresponding analyses (DCA) diagram illustrating the position of the Katian, Hirnantian and Juuru (Rhuddanian) clusters. Axis 1 with the eigenvalue of 0.9796 explaining the large part of the total variation can be attributed to stratigraphy. The interpretation of axis 2 (eigenvalue 0.5921 ) and axis 3 (eigenvalue 0.2853 ) is not as obvious, but can be ascribed to ecological factors. 

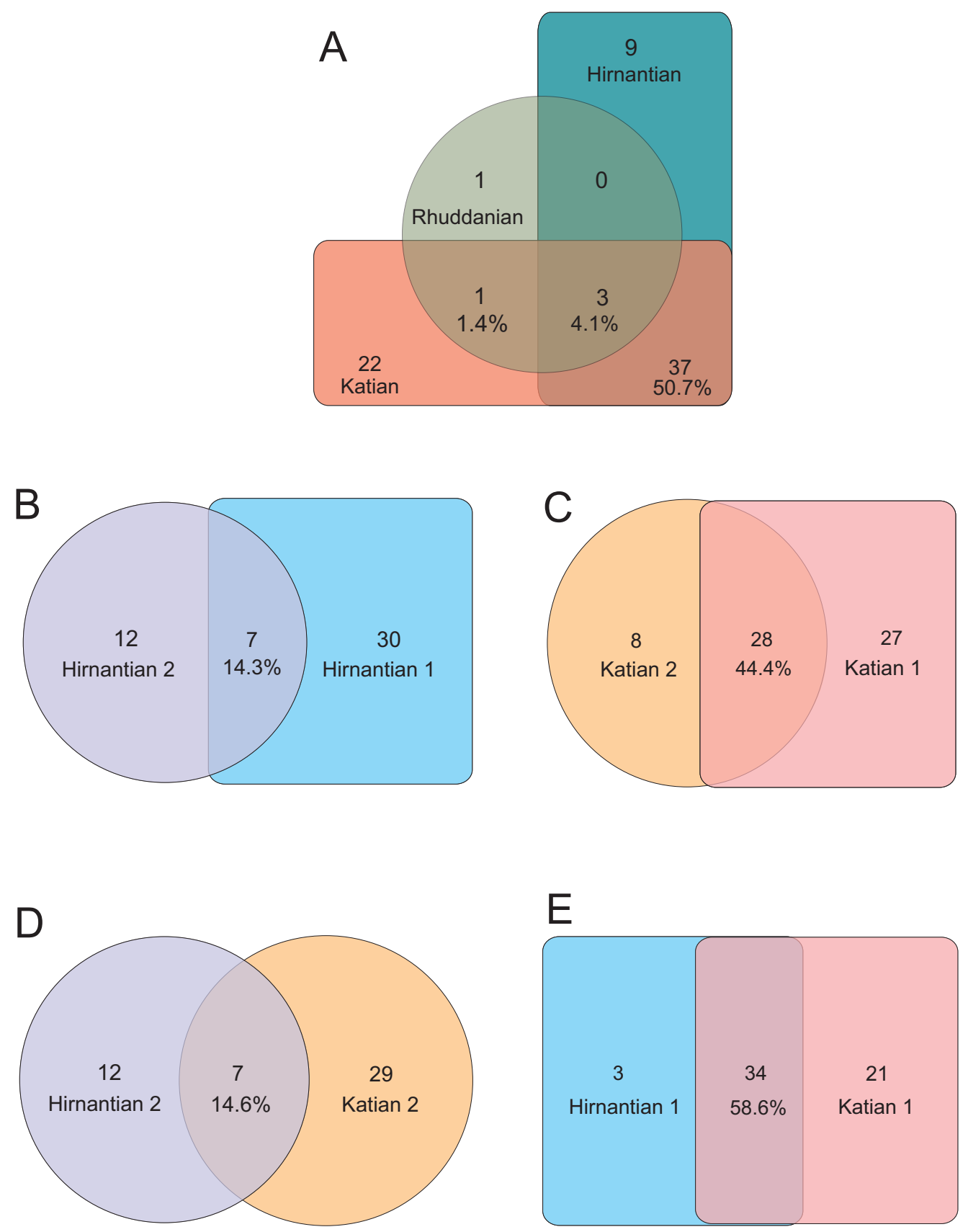

Fig. 7. Venn diagrams showing unique and shared genera among the Katian, Hirnantian and Juuru (Rhuddanian) clusters (A); clusters Hirnantian 1 and Hirnantian 2 (B); clusters Katian 1 and Katian 2 (C); clusters Hirnantian 2 and Katian 2 (D); clusters Hirnantian 1 and Katian 1 (E). 
Some of its principal components, like the genus Aechmina, were present already in the pre-Hirnantian in both Ibero-Armorica, Precordillera (Gondwana) and the Cautley district (Avalonia) (Williams et al. 2001; Meidla et al. 2013) but they have not previously been recorded in the Katian of Estonia and adjacent areas. Several genera make their first appearance here. The H. harparum association has no common species with lower Silurian ostracod fauna and nearly all specific genera got extinct in the late Hirnantian (Meidla 2007).

\section{OSTRACODS ACROSS THE KATIAN- HIRNANTIAN TRANSITION}

Being located close to the equator, the marginal shelf basins of the Baltica Palaeocontinent and their ostracod faunas were probably only indirectly affected by the cooling that developed closer to the South Pole and the centre of glaciation. The glacial dynamics is inferred in the BPB from $\delta^{18} \mathrm{O}$ and $\delta^{13} \mathrm{C}$ curves that are largely parallel for the Hirnantian (Brenchley 2004). The $\delta^{13} \mathrm{C}$ starts rising at the Katian-Hirnantian boundary, within the Spinachitina taugourdeaui chitinozoan Biozone. As suggested also by Wang et al. (2019), this biozone seemingly spans over the Katian-Hirnantian boundary interval in the palaeobasin, from low (as in the Tartu core; Põldvere 1998; Bauert et al. 2014) to slightly elevated (e.g. Brenchley et al. 2003; Kaljo et al. 2008; Hints et al. 2010, 2014) $\delta^{13} \mathrm{C}$ values.

During the late Katian, parts of the BPB were inhabited by ostracod associations which are quite distinctive at species level but rather cohesive in generic composition. The diversity indices of pre-Hirnantian communities are high both in the shallower $(D=0.72$ $0.89)$ and the deeper part $(D=0.50-0.77)$ of the basin (see also Figs 5,8 ) but show a lowering trend close to the Katian-Hirnantian boundary. This trend is especially conspicuous in the deeper part of the basin, where the diversity index in some sections drops below 0.5 (Fig. 8). According to Kaljo et al. (2008), the first pulse of the endOrdovician mass extinction might have begun already in pre-Hirnantian times, not at the beginning of the Hirnantian as commonly suggested. The ostracod dynamics supports this idea.

The pre-Hirnantian ostracod clusters (Katian 1 and Katian 2) contain material from inner shelf areas of both the Estonian and Lithuanian shelves. The assemblages in these areas are only moderately similar. Although a number of species are common to the two areas (e.g. Steusloffina cuneata, Rectella romboformis, Microcheilinella lubrica, Warthinia minuta, Kroemmelbeinia spina, Baltonotella limbata), the Lithuanian samples seem to group closely together evidently because of collection bias (podocopes are undersampled or omitted, as stated by Sidaravičiene 1992, p. 8). The Estonian and Lithuanian shelves both represented shallow-water inner shelf environments, being separated by the deeper-water Livonian Basin (deeper shelf areas). The uppermost fossiliferous Ordovician in the Paroveja section in the Lithuanian Shelf comprises the late Katian Paroveja Formation (see Hints et al. 1989) but the overlying Saldus Formation is barren of fossils (Sidaravičiene 1996). A similar barren unit occurs in the boundary interval in several sections in Central Estonia (e.g. Ruskavere, Laeva, Viljandi; Meidla 1996b). It is underlain by the Halliku Formation containing a long-ranging but distinctly pre-Hirnantian assemblage. Further eastwards of Paroveja, the Lithuanian sections lack both the cold-water binodicope-dominated ostracod fauna and likely also the Hirnantian (e.g. Butkunai, Sutkai and Ledai drill cores in Sidaravičiene 1996).

Juxtaposing $\delta^{13} \mathrm{C}$ fluctuations and faunal changes in the North Estonian Männamaa (F-367) drill core shows that $\delta^{13} \mathrm{C}$ values start rising already in the uppermost preHirnantian. By that level, many pre-Hirnantian species have disappeared; the remaining species and newly appearing species are almost all podocopes (Meidla \& Tinn 2008). A sedimentary gap and the fact that carbon isotopic zones $\mathrm{BC} 14$ and at least most of $\mathrm{BC} 15$ are missing here are probably partly responsible for such an ostracod faunal change here (Fig. 8). Still, a similar trend in diversity can also be observed in the Taagepera drill core (drop from 0.79 to 0.59 concurrently with the rise in $\delta^{13} \mathrm{C}$ values), the Jurmala drill core (diversity drop from 0.88 to 063 concurrently with the rise in $\delta^{13} \mathrm{C}$ values) and in the Valga-10 drill core where the pre-Hirnantian ostracods almost completely disappear several metres before the Katian-Hirnantian boundary (Fig. 8).

Podocopes of the Livonian and Scandinavian basins are represented by only two species (Duplicristatia asymmetrica and Rectella sturiensis). Curiously enough, an eridostracan species, Cryptophyllus pius Truuver \& Meidla, appears in great abundance in the Kętrzyn drill core (Northeast Poland) and is by far the dominant Hirnantian species there (Truuver \& Meidla 2015). This may indicate that the overall facies zonation within the BPB during the Hirnantian is insufficiently known and the deeper facies may be underrepresented in the descriptions of collections.

The UPGMA cluster analysis supported by AMOSIM shows that the pre-Hirnantian and Hirnantian associations of the deeper-water Livonian Basin (Katian 2 and Hirnantian 2) are distinct (see also Fig. 3) and stand well apart from one another (Fig. 6). This demonstrates a remarkable faunal change. In many locations (e.g. Taagepera and Paroveja drill cores) the disappearance of several preHirnantian species, especially palaeocopes, precedes the 

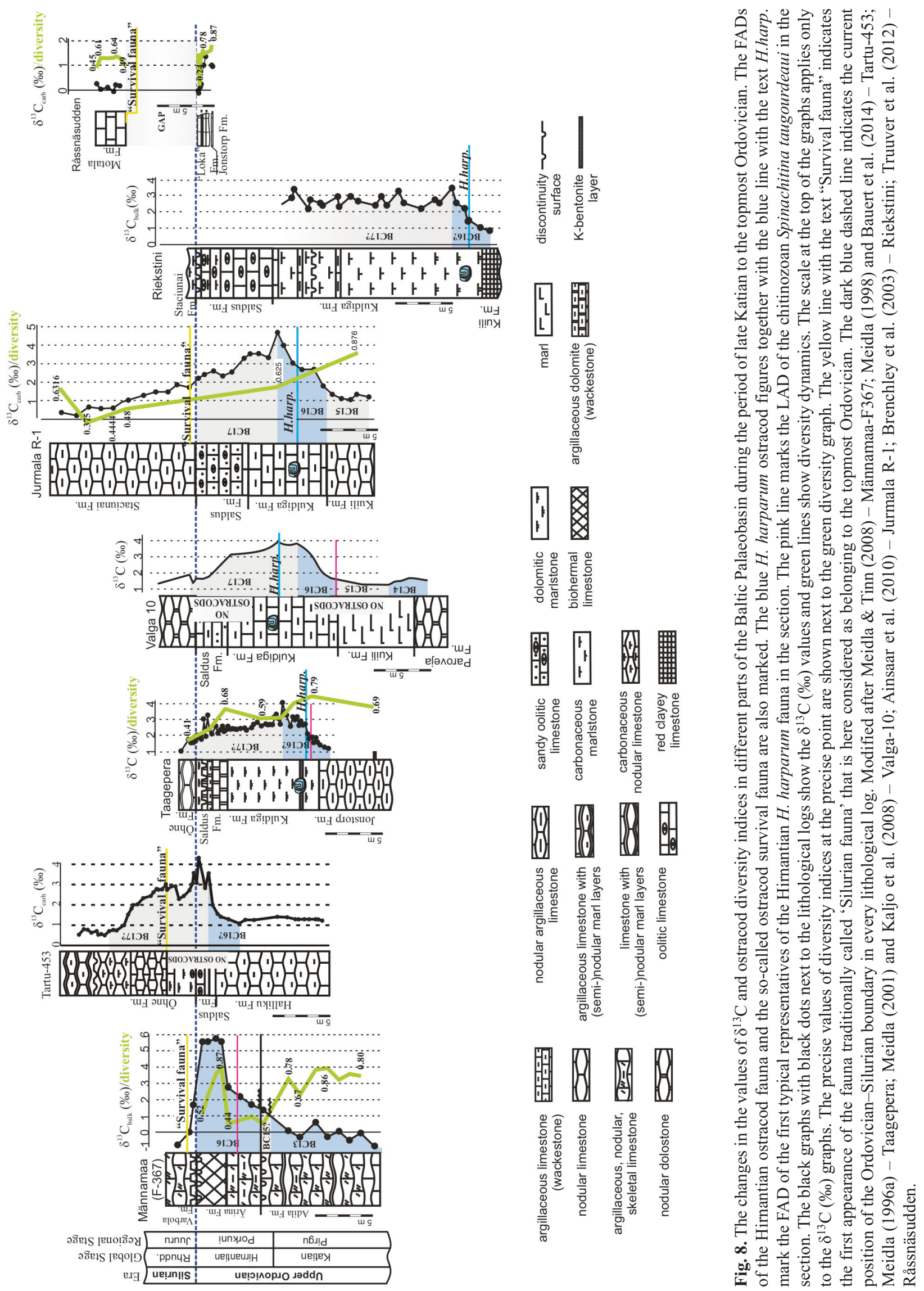
rise in $\delta^{13} \mathrm{C}$ levels (Fig. 8; see also supplementary online material: ostracod data matrix at https://doi.org/10.23679/505). The newly appearing Hirnantian 2 assemblage that is considered a typical cold-water fauna (Meidla 1996a) does not appear simultaneously with a carbon stable isotope rise, but close to or at the peak of it. This assemblage also seems to appear somewhat earlier in the deeper part of the basin than in the shallower part (Fig. 8). Some species of the H. harparum fauna, e.g. Circulinella gailitae and Aechmina groenwalli, appear slightly before the other typical members of this assemblage but still clearly after the start of the rapid rise of the carbon isotope curve and always after the LAD of S. taugourdeaui (see, for example, Brenchley et al. 2003). A slightly delayed appearance of the typical Hirnantian brachiopod assemblage in the area is also demonstrated or reported in several papers (e.g. Brenchley et al. 2003; Harper \& Hints 2015).

The diachroneity of the appearance of species of the Hirnantia brachiopod fauna has been recorded also in the Yangtze region, China, where the FADs of the Hirnantian brachiopods are highly variable (Chen et al. 2000). In shallow-water sections this fauna appears at the lower boundary of the Normalograptus extraordinarius $-N$. ojsuensis graptolite Biozone, in deeper-water sections somewhat above the base of the Hirnantian Stage. Chen et al. (2000) explain this diachroneity with basin development during the Hirnantian: a drop in sea-level affected the shallower parts of the basin and created suitable living conditions for the Hirnantia fauna there first. As the shallowing continued, suitable conditions developed in the (formerly) deeper parts of the basin (Chen et al. 2000). Gradual sealevel shallowing might be a possible explanation of the diachroneity of the H. harparum ostracod assemblage in the BPB too. The shallower sections contain only basal Hirnantian strata; in many sections it is entirely missing. It is possible that the $H$. harparum fauna reached only the deeper-water sections and sedimentary gaps have eroded all of the ostracod-bearing material in shallow-water sections.

One of the richest Hirnantian ostracod faunas of that kind has been described from Borenshult (Southeast Sweden). This association, called the Borenshult fauna or the Harpabollia harparum association, consists of 26 species, of which four, Circulinella gailitae, Aechmina groenwalli, Harpabollia harparum and Rectella sturiensis, form about $77 \%$ of the entire fauna. Binodicopes are very abundant but there are also extraordinarily many palaeocope species (e.g. Laevanotella nonsulcata, Gryphiswaldensia plavinensis) which, according to Meidla (2007), indicate that the association is probably a mixture of pre-Hirnantian and Hirnantian material. The rock material prepared for ostracods from the Borenshult locality comes from the horizon containing also abundant
Stegerhynchus eoborealis Rong, Jin, Zhan \& Bergström, Dalmanella testudinaria (Dalman), Hindella cassidea (Dalman), Hirnantia sagittifera (McCoy) and many other species (Rong et al. 2008). This confirms the co-occurrence of the typical Hirnantian H. harparum ostracod assemblage with the Hirnantian fauna sensu lato. Although the old samplings from Borenshult likely contain material from several horizons, the simultaneous occurrence of brachiopods, ostracods and graptolites on the same slab indicates that the Harpabollia association definitely ranges into the M. persculptus Biozone and cooccurs with Stegerhynchus eoborealis. The latter species is considered typical of the Edgewood Province - one of the three typical Hirnantian brachiopod provinces established based on the latitudinal differences in the distribution of the shelly fauna (Candela 2015; Wang et al. 2017). This section and the particular slab are one of the few occurrences of fossils in the OrdovicianSilurian transition interval within the BPB where the material can be distinctly dated by graptolites.

Changes in faunal composition at the lower boundary of the Ärina Formation (North Estonia) and the beginning of the positive excursion of $\delta^{13} \mathrm{C}$ at the same level, together with the chitinozoan correlation, have served as the basis for considering that the Porkuni Regional Stage and the global Hirnantian Stage are coeval. The generic composition of palaeocopes experiences a strong reduction in the topmost Katian but that of podocopes in the cluster Hirnantian 1 remains nearly the same (Meidla 1996b; see Fig. 3). Although many species in the North Estonian Shelf are long-ranging (e.g. Bairdiocypris indeterminatus, Microcheilinella lubrica, Steusloffina cuneata), the Hirnantian 1 cluster in the Ärina Formation contains some newly introduced palaeocope and podocope species (Medianella aequa, Apatochilina falacata, Kiesowia(?) decima, Foramenella porkuniensis, Loculibolbina unica, Gryphiswaldensia plicata, Bulbosclerites unicornis) but no new genera (Meidla 1996b). This assemblage appears within strata that are confined to the S. taugourdeaui chitinozoan Biozone (Hints et al. 2000) and is therefore believed to be older than the Harpabollia assemblage. The Ärina Formation has been considered as the basal part of the Porkuni Regional Stage in previous publications but its ostracod assemblage (Hirnantian 1 cluster) stays statistically apart from the Hirnantian 2 cluster of the Livonian Basin (Hirnantian 2) (see Figs 3, 6).

The appearance of the specific Harpabollia fauna is documented in the sections of the Livonian Basin before the peak of the Hirnantian glaciation but distinctly above the S. taugourdeaui Biozone. In Fig. 7, the clusters Katian 1, Katian 2 and Hirnantian 1 overlap against axis 1, which explains a large part of the total variation in assemblages (eigenvalue 0.9796). On the basis of the taxonomic composition of ostracods in different Ordovician clusters 
and the distinct positioning of the Hirnantian clusters against the $S$. taugourdeaui chitinozoan Biozone, we tend to interpret the differences along axis 1 as stratigraphical and, hence, consider that the clusters Hirnantian 1 and Hirnantian 2 describe successive assemblages. This agrees with the suggestion that the Ärina Formation may be equivalent to only the basal part of the Kuldiga Formation (Meidla 1996b). The calculated eigenvalue for axis 2 is 0.5921 and can be ascribed to ecological factors (peculiarity of the reef facies of the cluster Hirnantian 1).

\section{From the Hirnantian into the Silurian - a major turnover in ostracods}

The Ordovician-Silurian boundary is fixed at the Silurian System GSSP site, in the Dob's Linn section in Scotland, being tied to the FAD of the zonal graptolite Akidograptus ascencus (Bergström et al. 2009). This boundary lacks graptolite control in Estonia and adjacent areas. The major faunal turnover that extinguished the Hirnantian brachiopod and ostracod fauna in the eastern part of the BPB was treated as the lower boundary of the Silurian system in the area for decades. Recent evidence shows that the Hirnantian isotopic carbon excursion (HICE) extends into the strata that were formerly considered as the lowermost Silurian and, hence, the position of the lower boundary of the Silurian needs to be adjusted in the area. Hints et al. (2014) have demonstrated that this boundary is likely drawn within or above the Ancyrochitina laevaensisSpinachitina fragilis chitinozoan Biozone.

The post-glacial (earlier referred to as 'basal Silurian') ostracod fauna in the area is not amply studied. Sarv (1970) described two assemblages from the Llandovery, the older of them comprising the Juuru and Raikküla regional stages. This assemblage contains some remnants of the Ordovician faunas (Cystomatochilina, Microcheilinella, Monoceratella, Steusloffina). Of the species, only Microcheilinella lubrica and Medianella longa proceed from the latest Ordovician into the Silurian. Sarv (ibid.) also documented the appearance of several palaeocope taxa (Aitilia senecta, Bolbiprimitia tamsaluensis, Kiltsiella rosensteinae, Monoceratella edita) and several podocopes (Steusloffina eris, Silenis estonus, Neckajatia modesta (= Altha modesta: Sarv 1970), Neoprimitiella litwaensis) and the leiocope Neoaparchites tenuicostatus (= Paraparchites tenuicostatus: Sarv 1970). The first occurrences of these taxa are mostly tied to the middle-upper parts of the Juuru Regional Stage. The first true beyrichiaceans, e.g. Aitilia, Craspedobolbina and Bingeria, first appear only in the Hilliste Formation (upper Rhuddanian) (Sarv 1970). The basal part of the Juuru Regional Stage is characterized by an impoverished ostracod assemblage where the postglacial dominant species belong to Microcheilinella and
Rectella and the species Longiscula smithii is very common.

Juxtaposing the $\delta^{13} \mathrm{C}$ curve and the appearance of the post-glacial ostracod fauna shows that the appearance of the low-diversity association is tied to the falling limb of the $\delta^{13} \mathrm{C}$ curve in Estonia and Latvia. The post-Hirnantian ostracods of the Lithuanian Shelf and the overall diversification pattern of ostracods above the Hirnantian event horizon in the BPB are rather tenuously documented (see Pranskevičius 1971, 1972).

The ostracod assemblage in the Råssnäsudden section (Östergötland, Lithuania) is much richer and more abundant, being likely considerably younger. On the basis of graptolite zonation, Bergström \& Bergström (1996, p. 40) suggest that the Motala Formation '... corresponds to an interval from the acinaces Zone to the revolutus Zone...', i.e. to the upper half of the Rhuddanian. Despite the probable younger age of the strata, the core of this ostracod assemblage is broadly the same as elsewhere in Baltoscandia where the post-glacial dominant species belong to Microcheilinella and Rectella and the species Longiscula smithii is very common. The Juuru cluster is very distinct in Fig. 3 and positioned apart in the detrended correspondence analysis (Fig. 6).

\section{CONCLUSIONS}

Although many authors have attributed the endOrdovician mass extinction to the beginning of the Hirnantian, the declining ostracod diversity curves indicate that the extinction appeared already in the late Katian, as suggested by Kaljo et al. (2008).

The cold-water and binodicope-dominated Harpabollia harparum ostracod assemblage does not appear simultaneously with the beginning of the carbon stable isotopic excursion but close to or at the peak of it and always above the LAD of $S$. taugourdeaui. The specific species composition (dominance of Cryptophyllus pius Truuver \& Meidla) in the Kętrzyn drill core (Northeast Poland) suggests a more complex biofacies pattern for the Hirnantian of the BPB than previously described.

The simultaneous existence of the binodicopedominated Harpabollia harparum ostracod assemblage and Stegerhynchus eoborealis Rong, Jin, Zhan \& Bergström, 2008, Dalmanella testudinaria (Dalman), Hindella cassidea (Dalman), Hirnantia sagittifera (McCoy) and Metabolograptus persculptus shows the cooccurrence of the typical Hirnantian $H$. harparum ostracod assemblage with the Hirnantian fauna sensu lato and confirms that the $H$. harparum assemblage definitely ranges into the M. persculptus Biozone. This material is one of the few occurrences of Hirnantian fossils within the BPB that can be directly dated by graptolites. 
The slightly impoverished palaeocope and podocopedominated ostracod assemblage in the Ärina Formation and its equivalents in the sections of the Scandinavian Basin assemblage appear within the $S$. taugourdeaui chitinozoan Biozone (Hints et al. 2000) and are therefore likely older than the Harpabollia assemblage.

The basal part of the Juuru Regional Stage (Hirnantian-Rhuddanian transition interval) is characterized by an impoverished ostracod assemblage dominated by Longiscula smithii and accompanied by Microcheilinella and Rectella species. This assemblage could be characterized as a survival fauna.

Acknowledgements. We would like to thank the reviewers Peep Männik and David J. Siveter for their useful comments on the manuscript. We are very grateful to Sigitas Radzevičius from the Faculty of Chemistry and Geosciences of Vilnius University for granting us access to Lithuanian ostracod material. This study was conducted with the support of project PRG836 'Tracing the origins of early Paleozoic stable carbon isotope excursions global, regional and local drivers' from the Estonian Research Council. The publication costs of this article were partially covered by the Estonian Academy of Sciences.

\section{Supplementary online data}

The supplementary material to this article is available at https://doi.org/10.23679/505. It includes the ostracod data matrix (locality, sample, stratigraphic and species data) used in the statistical analyses with the palaeontological statistics software PAST (Hammer et al. 2001). The information is derived from newly collected data from core sections and outcrops and relevant literature, which was examined in the course of the compilation of this database. The names of samples are presented as abbreviations for statistical analyses using the PAST program. The same abbreviations are used in the cluster analyses in Fig. 3.

\section{REFERENCES}

Ainsaar, L., Kaljo, D., Martma, T., Meidla, T., Männik, P., Nõlvak, J. \& Tinn, O. 2010. Middle and Upper Ordovician carbon isotope chemostratigraphy in Baltoscandia: A correlation standard and clues to environmental history. Palaeogeography, Palaeoclimatology, Palaeoecology, 294, 189-201.

Ainsaar, L., Truumees, J. \& Meidla, T. 2015. The position of the Ordovician-Silurian boundary in Estonia tested by high-resolution $\delta^{13} \mathrm{C}$ chemostratigraphic correlation. In Chemostratigraphy: Concepts, Techniques and Applications (Ramkumar, M., ed.), pp. 395-412. Elsevier, Amsterdam.

Bauert, H., Ainsaar, L., Põldsaar, K \& Sepp, S. 2014. $\delta^{13}$ C chemostratigraphy of the Middle and Upper Ordovician succession in the Tartu-453 drillcore, southern Estonia, and the significance of the HICE. Estonian Journal of Earth Sciences, 63, 195-200.

Bergström, S. M. \& Bergström, J. 1996. The OrdovicianSilurian boundary successions in Östergötland and Västergötland, S. Sweden. GFF, 118, 25-42.

Bergström, S. M., Xu, C., Gutiérrez-Marco, J. C. \& Dronov, A. 2009. The new chronostratigraphic classification of the Ordovician System and its relations to major regional series and stages and to $\delta^{13} \mathrm{C}$ chemostratigraphy. Lethaia, 42, 97-107.

Bergström, S. M., Calner, M., Lehnert, O. \& Noor, A. 2011. A new upper Middle Ordovician-Lower Silurian drillcore standard succession from Borenshult in Östergötland, southern Sweden, 1. Stratigraphical review with regional comparisons. GFF, 133, 149-171.

Berry, W. B. N \& Boucot, A. J. 1973. Glacio-eustatic control of Late Ordovician-Early Silurian platform sedimentation and faunal changes. Geological Society of America Bulletin, 84, 275-284.

Boomer, I., Horne, D. J. \& Slipper, I. J. 2003. The use of ostracods in paleoenvironmental studies, or what can you do with an ostracod shell? Paleontological Society Papers, 9, 153-180.

Brenchley, P. J. 2004. End Ordovician extinction. In Mass Extinctions and Their Aftermath (Hallam, A. \& Wignall, B. P., eds), pp. 81-83. Oxford University Press.

Brenchley, P. J. \& Newall, G. 1984. Late Ordovician environmental changes and their effect on faunas. In Aspects of the Ordovician System (Bruton, D. L., ed.), Palaeontological Contributions from the University of Oslo, 295, 65-79.

Brenchley, P. J., Marshall, J. D., Carden, G. A. F., Robertson, D. B. R., Long, D. G. F., Meidla, T., Hints, L. \& Anderson, T. F. 1994. Bathymetric and isotopic evidence for a short-lived Late Ordovician glaciation in a greenhouse period. Geology, 22, 295-298.

Brenchley, P. J., Carden, G. A., Hints, L., Kaljo, D., Marshall, J. D., Martma, T., Meidla, T. \& Nõlvak, J. 2003. High-resolution stable isotope stratigraphy of Upper Ordovician sequences: Constraints on the timing of bioevents and environmental changes associated with mass extinction and glaciation. Geological Society of America Bulletin, 115, 89-104.

Buggisch, W., Joachimski, M. M., Lehnert, O., Bergström, S. M., Repetski, J. E. \& Webers, G. F. 2010. Did intense volcanism trigger the first Late Ordovician icehouse? Geology, 38, 327-330.

Candela, Y. 2015. Evolution of Laurentian brachiopod faunas during the Ordovician Phanerozoic sea level maximum. Earth-Science Reviews, 141, 27-44.

Chen, X., Rong, J., Mitchell, C. E., Harper, D. A. T., Fan, J., Zhan, R., Zhang, Y., Li, R. \& Wang, Y. 2000. Late Ordovician to earliest Silurian graptolite and brachiopod biozonation from the Yangtze region, South China with a global correlation. Geological Magazine, 137, 623-650.

Clapham, M. E. 2011. Ordination methods and the evaluation of Ediacaran communities. In Quantifying the Evolution of Early Life (Laflamme, M., Schiffbauer, J. D. \& Dornbos, S. Q., eds), Topics in Geobiology, 36, 3-21. 
Correa-Metrio, A., Dechnik, Y., Lozano-García, S. \& Caballero, M. 2014. Detrended correspondence analysis: A useful tool to quantify ecological changes from fossil data sets. Boletín de la Sociedad Geológica Mexicana, 66, 135-143.

Finnegan, S., Bergmann, K., Eiler, J. M., Jones, D. S., Fike, A., Eisenman, I., Hughes, N. C., Tripati, A. K. \& Fischer, W. W. 2011. The magnitude and duration of late OrdovicianSilurian glaciation. Science, 331, 903-906.

Finnegan, S., Heim, N. A., Shanan, E. P. \& Fisher, W. W. 2012. Climate change and the selective signature of the Late Ordovician mass extinction. PNAS, 109, 6829-6834.

Hallam, A. \& Wignall, P. B. 1997. Mass Extinctions and Their Aftermath. Oxford University Press, 328 pp.

Hammarlund, E. U., Dahl, T. W., Harper, D. A. T., Bond, D. P. G., Nielsen, A. T., Bjerrum, C. J., Schovsbo, N. H., Schönlaub, H. P., Zalasiewicz, J. A. \& Canfield, D. E. 2012. A sulfidic driver for the end-Ordovician mass extinction. Earth and Planetary Science Letters, 331-332, 128-139.

Hammer, Ø. \& Harper D. A. T. 2005. Paleontological Data Analysis. Blackwell Publishing, 344 pp.

Hammer, Ø., Harper, D. A. T. \& Ryan, P. D. 2001. PAST: Paleontological Statistics software package for education and data analysis. Palaeontologica Electronica, 4(1), $9 \mathrm{pp}$.

Harper, D. A. T. \& Hints, L. 2015. Hirnantian (Late Ordovician) brachiopod faunas across Baltoscandia: A global and regional context. Palaeogeography, Palaeoclimatology, Palaeoecology, 444, 71-83.

Harper, D. A. T., Hammarlund, E. U. \& Rasmussen, C. M. Ø. 2014. End Ordovician extinctions: a coincidence of causes. Gondwana Research, 25, 1294-1307.

Harris, M. T., Sheehan, P. M., Ainsaar, L., Hints, L., Männik, P., Nõlvak, J. \& Rubel, M. 2004. Upper Ordovician sequences of western Estonia. Palaeogeography, Palaeoclimatology, Palaeoecology, 210, 135-148.

Heberle, H., Meirelles, G. V., da Silva, F. R., Telles, G. P. \& Minghim, R. 2015. InteractiVenn: a web-based tool for the analysis of sets through Venn diagrams. $B M C$ Bioinformatics, 16, 169.

Herrmann, A. D., Macleod, K. G. \& Leslie, S. A., 2010. Did a volcanic mega-eruption cause global cooling during the late Ordovician? Palaios, 25, 831-836.

Hints, L. \& Männik, P. 2014. Stop A10: Porkuni quarry. In 4th Annual Meeting of IGCP 591, Estonia, 10-19 June 2014, Abstracts and Field Guide (Bauert, H., Hints, O., Meidla, T. \& Männik, P., eds), pp. 167-172. University of Tartu.

Hints, L., Meidla, T., Nõlvak, J. \& Sarv, L. 1989. Some specific features of the Late Ordovician evolution in the Baltic basin. Proceedings of the Academy of Sciences of the Estonian SSR, Geology, 38, 83-87.

Hints, L., Oraspõld, A. \& Kaljo, D. 2000. Stratotype of the Porkuni Stage with comments on the Röa Member (uppermost Ordovician, Estonia). Proceedings of the Estonian Academy of Sciences, Geology, 49, 177-199.

Hints, L., Hints, O., Kaljo, D., Kiipli, T., Männik, P., Nõlvak, J. \& Pärnaste, H. 2010. Hirnantian (latest Ordovician) bioand chemostratigraphy of the Stirnas-18 core, western Latvia. Estonian Journal of Earth Sciences, 59, 1-24.
Hints, O., Martma, T., Männik, P., Nõlvak, J., Põldvere, A., Shen,Y. \& Viira, V. 2014. New data on Ordovician stable isotope record and conodont biostratigraphy from the Viki reference drill core, Saaremaa Island, western Estonia. GFF, 136, 100-104.

Kaljo, D., Hints, L., Martma, T. \& Nõlvak, J. 2001. Carbon isotope stratigraphy in the latest Ordovician of Estonia. Chemical Geology, 175, 49-59.

Kaljo, D., Martma, T., Männik, P. \& Viira, V. 2003. Implications of Gondwana glaciations in the Baltic late Ordovician and Silurian and a carbon isotopic test of environmental cyclicity. Bulletin de la Societe Geologique de France, 174, 59-66.

Kaljo, D., Hints, L., Männik, P. \& Nõlvak, J. 2008. The succession of Hirnantian events based on data from Baltica: brachiopods, chitinozoans, conodonts, and carbon isotopes. Estonian Journal of Earth Sciences, 57, 197-218.

Kump, L. R., Arthur, M. A., Patzkowsky, M. E., Gibbs, M. T., Pinkus, D. S. \& Sheehan, P. M. 1999. A weathering hypothesis for glaciation at high atmospheric $p \mathrm{CO}_{2}$ during the Late Ordovician. Palaeogeography, Palaeoclimatology, Palaeoecology, 152, 173-187.

Lapinskas, P. 2004. Silūras [Silurian]. In Evolution of Earth Crust and Its Resources in Lithuania (Baltrūnas, V., ed.), pp. 66-72. Geologijos ir geografijos institutas, Vilniaus Universitetas [in Lithuanian].

Laškovas, J. 2004. Ordovikas [Ordovician]. In Evolution of Earth Crust and Its Resources in Lithuania (Baltrūnas, V., ed.), pp. 56-66. Geologijos ir geografijos institutas, Vilniaus Universitetas [in Lithuanian].

Lenton, T. M., Crouch, M., Johnson, M., Pires, N. \& Dolan, L. 2012. First plants cooled the Ordovician. Nature Geoscience, 5, 86-89.

Long, A. J., Large, R. R., Lee, M. S. Y., Benton, M. J., Danyushevsky, L. D., Chiappe, L. M., Halpin, J. A., Cantrill, D. \& Lottermoser, B. 2015. Severe selenium depletion in the Phanerozoic oceans as a factor in the three global mass extinction events. Gondwana Research, 36, 209-218.

Lukševičs, E., Stinkulis, G., Mūrnieks, A. \& Popovs, K. 2012. Geological evolution of the Baltic Artesian Basin. In Highlights of Groundwater Research in the Baltic Artesian Basin (Dēlina, A., Kalvāns, A., Saks, T., Bethers, U. \& Vircavs, V., eds), pp. 7-52. University of Latvia, Riga.

Männik, P. 2014. The Silurian System in Estonia. In 4th Annual Meeting of IGCP 591, Estonia, 10-19 June 2014, Abstracts and Field Guide (Bauert, H., Hints, O., Meidla, T. \& Männik, P., eds), pp. 123-128. University of Tartu, Tartu.

Männil, R. \& Meidla, T. 1994. The Ordovician System of the East European Platform (Estonia, Latvia, Lithuania, Byelorussia, parts of Russia, the Ukraine and Moldova). In The Ordovician System of the East European Platform and Tuva (Southeastern Russia) (Webby, B. D. \& Williams, S. H., eds), IUGS Publication, 28A, 1-52.

Marshall, J. D. \& Middleton, P. D. 1990. Changes in marine isotopic composition and the late Ordovician glaciation. Journal of the Geological Society London, 147, 1-4.

Meidla, T. 1996a. Latest Ordovician ostracods of Baltoscandia. In WOGOGOB-94 Symposium, Working Group of 
Ordovician Geology of Baltoscandia, Bornholm-94 (Stouge, S., ed.), Geological Survey of Denmark and Greenland, 98, 65-71.

Meidla, T. 1996b. Late Ordovician ostracodes of Estonia. Fossilia Baltica, 2, 1-222.

Meidla, T. 1998. Ordovician. In Tartu (453) Drillcore (Põldvere, A., ed.), Estonian Geological Sections, 1, 11-17.

Meidla, T. 2001. Distribution of ostracodes in the Valga (10) section. In Valga 10 Drill Core (Põldvere, A., ed.), Estonian Geological Sections, 3, 14-16.

Meidla, T. 2007. Ostracods from the Upper Ordovician Borenshult fauna, Sweden. GFF, 129, 123-132.

Meidla, T. \& Tinn, O. 2008. Distribution of Upper Ordovician ostracods. In Männamaa (F-367) Drill Core (Põldvere, A., ed.), Estonian Geological Sections, 9, 24-27.

Meidla, T., Ainsaar, L. \& Truuver, K. 2011. Ostracods in Baltoscandia through the Hirnantian crisis. Cuadernos del Museo Geominero, 14, 353-357.

Meidla, T., Tinn, O., Salas, M. J., Williams, M., Siveter, D., Vandenbroucke, T. \& Sabbe, K. 2013. Biogeographical patterns of Ordovician ostracods. In Early Palaeozoic Palaeobiogeography and Palaeogeography (Harper, D. A. T. \& Servais, T., eds), Geological Society, London, Memoirs, 38, 337-354.

Meidla, T., Ainsaar, L. \& Hints, O. 2014. The Ordovician System in Estonia. In 4th Annual Meeting of IGCP 591, Estonia, 10-19 June 2014, Abstracts and Field Guide (Bauert, H., Hints, O., Meidla, T. \& Männik, P., eds), pp. 116-122. University of Tartu, Tartu.

Modliński, Z. \& Podhalańska, T. 2010. Outline of the lithology and depositional features of the lower Paleozoic strata in the Polish part of the Baltic region. Geological Quarterly, 54, 109-121.

Mohibullah, M., Williams, M., Vandenbroucke, T. R. A., Sabbe, K. \& Zalasiewicz, J. A. 2012. Marine ostracod provinciality in the Late Ordovician of Palaeocontinental Laurentia and its environmental and geographical expression. PLoS ONE, 7, e41682.

Morris, J. L., Puttick, M. N., Clark, J. W., Edwards, D., Kenrick, P., Pressel, S., Wellman, C. H., Yang, Z., Schneider, H. \& Donoghue, P. C. J. 2018. The timescale of early land plant evolution. PNAS, 115, 10.

Nõlvak, J., Hints, O. \& Männik, P. 2006. Ordovician timescale in Estonia: recent developments. Proceedings of the Estonian Academy of Sciences, Geology, 55, 95-108.

Põldvere, A. 1998. Tartu (453) drill core. Estonian Geological Sections, 1, 1-48.

Pranskevičius, A. A. 1971. K paleontologicheskoj kharakteristike nizhnego silura Yuzhnoj Pribaltiki (dannye izucheniya ostrakod) [To the paleontological characteristic of the Lower Silurian of the southern Baltic area (data of the Ostrakod Study]. In Paleontologiya i stratigrafiya Pribaltiki i Belorussii, III [Palaeontology and Stratigraphy of the Baltic and the Byelorussia, III] (Grigelis, A. A., ed.), pp. 61-70. Mintis, Vilnius [in Russian, with English summary].

Pranskevičius, A. 1972. Ostrakody silura Yuzhnoj Pribaltiki [South Baltic Silurian Ostracoda]. Izvestiya akademii nauk LitNIGRI (Transactions of the Lithuanian Scientific-Research Geological Survey Institute), 15, 1-280 [in Russian].
Rasmussen, C. M. Ø. \& Harper, D. A. T. 2011. Did the amalgamation of continents drive the end Ordovician mass exctinction? Palaeogeography, Palaeoclimatology, Palaeoecology, 311, 48-62.

Reily, L., Adôrno, R. R., do Carmo, D. A., Salas, M. J., Cardoso da Silvia Rodrigues, L., Denezine, M. \& Zabini, C. 2018. Tridimensional ostracoda assemblage from Vila Maria Formation, Ordovician/Silurian, Paraná Basin Brazil. In Anais do $49^{\circ}$ Congresso Brasileiro de Geologia, 20 a 24 de agosto de 2018 - Rio de Janeiro (Palermo, N., de Araújo, H. I. Jr, Machado, F. B., Corval, A., de Castro Valente, S. \& Dal' Bó, P. F., eds), p. 1365.

Rong, J., Jin, J., Zhan, R. \& Bergström, J. 2008. The earliest known Stegerhynchus (Rhynchonellida, Brachiopoda) from the Hirnantian strata (uppermost Ordovician) at Borenshult, Östergötland, Sweden. GFF, 130, 21-30.

Rosenau, N. A., Herrmann, A. D. \& Leslie, S. A. 2012. Conodont apatite $\delta^{18} \mathrm{O}$ values from a platform margin setting, Oklahoma, USA: Implications for initiation of Late Ordovician icehouse conditions. Palaeogeography, Palaeoclimatology, Palaeoecology, 315-316, 172-180.

Saltzman, M. R. \& Young, S. A. 2005. Long-lived glaciation in the Late Ordovician? Isotopic and sequencestratigraphic evidence from western Laurentia. Geology, 33, 109-112.

Sarv, L. 1970. Ostrakody [Ostracodes]. In Silur Éstonii [The Silurian of Estonia] (Kaljo, D., ed.), pp. 157-170. Valgus, Tallinn [in Russian].

Schallreuter, R. E. L. \& Siveter, D. J. 1985. Ostracodes across the Iapetus Ocean. Palaeontology, 28, 577-598.

Sell, B., Ainsaar, L. \& Leslie, S. 2013. Precise timing of the Late Ordovician (Sandbian) super-eruptions and associated environmental, biological, and climatological events. Journal of the Geological Society London, 170, 711-714.

Sheehan, P. 1973. The relation of Late Ordovician glaciation to the Ordovician-Silurian changeover in North American brachiopod faunas. Lethaia, 6, 147-154.

Sidaravičiene, N. 1992. Ostrakody ordovika Litvy [Ordovician Ostracods of Lithuania]. LitNIGRI, Vilnius, 252 pp. [in Russian].

Sidaravičiene, N. 1996. Biostratigrafiya ordovikskikh ostrakod Litvy [Lithuanian Ordovician Ostracod Biostratigraphy]. Geological Institute, Vilnius, 81 pp. [in Lithuanian, with English summary].

Siveter, D. J. 2009. The Ordovician. In Ostracods in British Stratigraphy (Whittaker, J. E. W. \& Hart, M. B., eds), pp. 15-44. The Micropalaeontological Society, Geological Society London.

Tinn, O., Meidla, T. \& Ainsaar, L. 2006. Arenig (Middle Ordovician) ostracods from Baltoscandia: Fauna, assemblages and biofacies. Palaeogeography, Palaeoclimatology, Palaeoecology, 241, 492-514.

Torsvik, H. \& Cocks, L. R. M. 2013. Gondwana from top to base in space and time. Gondwana Research, 24, 999-1030.

Torsvik, T. \& Cocks, L. 2017. Ordovician. In Earth History and Palaeogeography (Torsvik, T. \& Cocks, L., eds), pp. 101123. Cambridge University Press.

Trotter, J. A., Williams, I. S., Barnes, C. R., Lécuyer, C. \& Nicoll, R. S. 2008. Did cooling oceans trigger Ordovician 
biodiversification? Evidence from conodont thermometry. Science, 321, 550-554.

Truuver, K. \& Meidla, T. 2015. A Hirnantian deep-water refuge for warm-water ostracods in Baltoscandia. Geological Quarterly, 59, 738-749.

Truuver, K., Meidla, T., Ainsaar, L., Bergström, L. \& Tinn, O. 2012. Stratigraphy of the Ordovician-Silurian boundary interval in Östergötland, Sweden, based on ostracod distribution and stable carbon isotopic data. GFF, 134, 295-308.

Turner, B. R., Armstrong, H. A. \& Holt, P. 2011. Visions of ice sheets in the early Ordovician greenhouse world: Evidence from the Peninsula Formation, Cape Peninsula, South Africa. Sedimentary Geology, 236, 226-238.

Vandenbroucke, T. R. A., Armstrong, H. A., Williams, M., Paris, F., Sabbe, K., Zalasiewicz, J. A., Nõlvak, J. \& Verniers, J. 2010. Epipelagic chitinozoan biotopes map a steep latitudinal temperature gradient for earliest Late Ordovician seas: Implications for a cooling Late Ordovician climate. Palaeogeography, Palaeoclimatology, Palaeoecology, 249, 202-219.

Vandenbroucke T. R. A., Emsbo, P., Munnecke, A., Nuns, N., Duponchel, L., Lepot, K., Quijada, M., Paris, F., Servais, T. \& Kiessling, W. 2015. Metal-induced malformations in early Palaeozoic plancton are harbingers of mass extinction. Nature Communications, 6 , 7966.

Vannier, J. M. C., Siveter, D. J. \& Schallreuter, R. E. L. 1989. The composition and palaeogeographical significance of the Ordovician ostracode faunas of Southern Britain, Baltoscandia, and Ibero-Armorica. Palaeontology, 32, 163-222.

Wang, G., Zhan, R., Huang, B. \& Percival, I. G. 2017. Coral faunal turnover through the Ordovician-Silurian transition in South China and its global implications for carbonate stratigraphy and macroevolution. Geological Magazine, 154, 829-836.

Wang, G., Zhan, R. \& Percival, I. 2019. The end-Ordovician mass extinction: A single-pulse event? Earth-Science Reviews, 192, 15-33.

Wilde, P. \& Berry, W. B. N. 1984. Destabilization of the oceanic density structure and its significance to marine extinction events. Palaeogeography, Palaeoclimatology, Palaeoecology, 48, 143-162.

Williams, M., Stone, P., Siveter, D. J. \& Taylor, P. 2001. Upper Ordovician ostracods from the Cautley district, northern England: Baltic and Laurentian affinities. Geological Magazine, 138, 589-607.

\title{
Muutused Balti paleobasseini Hilis-Ordoviitsiumi ostrakoodikooslustes
}

\author{
Karin Truuver, Tõnu Meidla ja Oive Tinn
}

Hilis-Ordoviitsiumi-aegne Balti paleobassein (BPB) oli rikkalike ja mitmekesiste ostrakoodikoosluste arenguks soodne keskkond. Ajastu lõpul toimunud järsk kliimamuutus, lühiajaline Hirnanti jääaeg ja sellega samaaegselt aset leidnud globaalne väljasuremissündmus tõid kaasa suured muutused ka siinses ostrakoodifaunas. Levikuandmete statistiline analüüs näitab, et Balti paleobasseini ostrakoodifaunas võib eristada mitmekesiseid jäätumiseelseid, liigivaesemaid jäätumisaegseid kooslusi ja tugevasti vaesunud jäätumisjärgset ostrakoodikooslust. Geograafiliselt eristuvad šelfi ülemise ja keskmise osa kooslus, kuid selline jaotus kehtib vaid jäätumiseelsete ning -aegsete koosluste kohta. Jälgi jäätumisjärgsest kooslusest leiti vaid üksikutest avašelfi läbilõigetest. Ostrakoodiandmestikku $\delta^{13} \mathrm{C}$ kõveratega kõrvutades ilmneb, et BPB-le tüüpiline jäätumisaegne Harpabollia harparum'i fauna ilmub alles isotoopkõvera tipu lähedal. See on ka tõenäoline põhjus, miks $H$. harparum'i fauna näib ilmuvat esmalt sügavaveelisemates läbilõigetes ja madalamaveelistes kas puudub või ilmub väikese hilinemisega. Enamikus Eesti põhjaosa ja Leedu idaosa madalaveelistes läbilõigetes Hirnanti lade puudub või on esindatud vaid lademe basaalkihtidega (näiteks Männamaa ja Puhmu läbilõige Põhja-Eestis).

Jäätumisjärgse perioodi ostrakoodikooslus on perekondade koosseisu arvestades pigem Hilis-Ordoviitsiumi koosluste jäänuk (survival fauna) kui jäätumisjärgset taastumist kajastav fauna (recovery fauna). Selle ilmumine $\delta^{13} \mathrm{C}$ kõvera jäätumise lõppu markeeriva languse taustal tähistab varem aktsepteeritud Ordoviitsiumi-Siluri piiri asukohta, kuid revideeritud kronoloogia alusel leidis see aset Hilis-Hirnanti eal. 